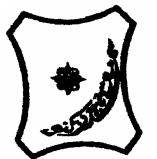

Bayero Journal of Pure and Applied Sciences, 4(2): 150 - 154

Received: June, 2011

Accepted: November, 2011

ISSN $2006-6996$

\title{
PHYSICO-CHEMICAL CHARACTERISTICS OF EFFLUENTS FROM GARRI PROCESSING INDUSTRIES IN BIDA, NIGER STATE, NIGERIA
}

\author{
Okafor, J. 0. \\ Department of Chemical Engineering, School of Engineering and Engineering Technology, \\ Federal University of Technology, Minna, Niger State, Nigeria. \\ jookai2003@yahoo.com
}

\begin{abstract}
Effluent and soil samples were collected from five different garri processing industries in Bida and analysed for conductivity, $\mathrm{pH}$, temperature, alkalinity, total hardness, dissolved oxygen, total suspended solids, total solids, nitrate, sulphate, chloride, sodium, potassium, calcium, cyanide ion, chemical oxygen demand and biochemical oxygen demand using standard methods. Soil samples were obtained five metres away from each discharge point. Results obtained from Efumadami discharge point showed that $\mathrm{pH}, B O D_{5}, C O D$, conductivity, total solids, suspended solid had the

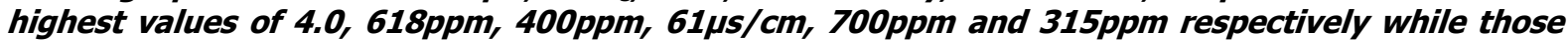

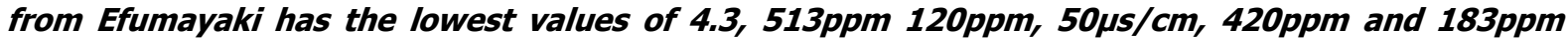
respectively. Most of the ions tested for in the soil samples increased as the depth of collection increased. The soil and effluent samples were observed to be grossly polluted with cyanide ion. The effluent samples contained 0.29-0.5ppm cyanide ion while those of soil samples is 0.3$0.62 \mathrm{ppm}$ all in contrast to World Health Organization maximum admissible limit of 0.07ppm. A twoway ANOVA showed that as the depth of collection of soil samples increased, cyanide concentration also increased.

Keywords: Effluent, Garri, Industries, WHO, ANOVA
\end{abstract}

INTRODUCTION

The threat to human and aquatic lives posed by industrial liquid and gaseous effluents cannot be overemphasized. Industries have long been implicated in the discharge of toxicants into the environment. Over 1.2 billion of World's city dwellers breath highly polluted air, ten percent of World's rivers are heavily polluted with discharges from food and allied industries and users of these rivers and streams are constantly exposed to health related risks due to this indiscriminate discharge of industrial effluents [Salami and Egwin, 1997].

Cassava (Manihot esculenta crantz) processing into garri involves several unit operations visa-vis, peeling, washing, grating, pressing and fermenting, sieving, roasting and drying. Traditional garri production is associated with the discharge of large amounts of water, hydrocyanic acid and organic matter in the form of peels and sieviates from the pulp as waste products. When these waste products are improperly disposed, they are left in mounds which generate offensive odours and unsightly scenarios [Food and Agricultural Organization, 2004].

The major component of the effluents out from garri processing industries is cyanide and in most cases, these effluents are channeled into pits where they continue to accumulate and sink gradually into the surrounding soils thereby posing a serious health and environmental hazard.

It is therefore intended in this study to determine the chemical characteristics of the effluent and soil within garri processing sites as well as ascertaining the level of cyanide contamination in the surrounding soil. This is with a view to designing strategies in combating environmental pollution problems caused by small scale garri processing industries scattered in many Nigerian cities and villages. For example, in a study by Okafor and Egwim [2004], it was reported that treatment of cassava effluent with locally developed absorbent reduced BOD and COD upto 50 and $75 \%$ respectively.

\section{MATERIALS AND METHODS}

Study Site.

The study area was Bida, a major town in Niger state, Nigeria. In this study, Bida refers to the area closed by latitude $9^{\circ} .06^{\prime} \mathrm{N}$ and $6^{\circ} .01^{\prime} \mathrm{E}$ longitude on the Nupe sandstone formation. The town lies within the basement complex and the Nupe Sand stone formation. The former comprises coarse sand or sandy clays and the later, essentially horizontal beds of weakly cemented clay, soft stones and sand stone. The soil in this area is made up of upland and depositional soils. The upland soil overlies thick sandstone and the major part consists of undulating plane with very deep soil. Soil in depositional areas are weakly developed hydromorptic soils [Madumelu and Okafor, 2002].

The study area was divided into five zones. These zones are Masaga, Efumayaki, Kotaworo, Edogifu and Efumadami. These zones are relatively urban areas and densely populated with garri processing cottage industries scattered in each zone. 


\section{Collection of Samples}

Soil samples were obtained five metres away from each discharge point. The soil samples labelled A, B, and $C$ were taken from the top soil, $50 \mathrm{~cm}$ and $1 \mathrm{~m}$ depths respectively. Effluent samples were collected from pits into which they discharged. These samples were collected from five different garri processing industries in Bida. These samples were stored in clean, 25 litre capacity plastic jerricans and were kept at room temperature for 24 hours prior to laboratory analysis.

\section{Determination of Conductivity and pH}

The conductivity of the effluent was determined using a conductivity meter (YSI Model 34) according to Salami and Egwin (1997) while the $\mathrm{pH}$ of the sample was determined with a pH metre (7020 HACH) following standardization with a buffer solution [Salami and Egwin, 1997].

\section{Determination of Temperature}

Temperature of the effluent and soil stock solution was determined using a mecury-in-glass thermometer $\left(0-100^{\circ} \mathrm{C}\right)$ in accordance with the method described by Madumelu and Okafor [2002].

\section{Determination of Alkalinity}

An effluent sample volume of $5.0 \mathrm{ml}$ was titrated against $0.02 \mathrm{M} \mathrm{HCl}$ to pinkish end point using methyl orange indicator as described by Salami and Egwin (1997).

\section{Determination of Total Hardness}

A $10 \mathrm{~cm}^{3}$ of the effluent sample was added to $2 \mathrm{~cm}^{3}$ buffer of $\mathrm{pH} 10$, followed by two drops of Eriochrome Black $\mathrm{T}$ indicator which was thoroughly mixed. The mixture was titrated against $0.01 \mathrm{M}$ ethylene diamine tetracetic acid (EDTA) until a light blue end point colour appeared [Salami and Egwin, 1997].

\section{Determination of Dissolved Oxygen (DO)}

A volume of $250 \mathrm{~cm}^{3}$ of the sample was mixed with $2 \mathrm{~cm}^{3}$ each of Manganese (II) Sulphate $\left(\mathrm{MnSO}_{4}\right)$, alkaline iodide - azide and $1 \mathrm{~cm}^{3}$ phosphoric acid $\left(\mathrm{H}_{3} \mathrm{PO}_{4}\right)$ with shaking. A $200 \mathrm{~cm}^{3}$ of the mixture was put into a $500 \mathrm{~cm}^{3}$ conical flask. The liberated iodine was titrated with $0.025 \mathrm{M}$ sodium thiosulphate $\left(\mathrm{Na}_{2} \mathrm{~S}_{2} \mathrm{O}_{3}\right)$ solution and $2 \mathrm{~cm}^{3}$ of starch indicator was added and titration continued until the first disappearance of the blue colour and the dissolved oxygen was found according to Salami and Egwin (1997).

\section{Determination of Total Suspended Solid}

Total suspended solid was determined using gravimetric method as outlined by Salami and Egwin (1997).

\section{Determination of Total Solids}

This was also carried out by gravimetric analysis using an evaporating dish as described by Ademoroti (1996a).

\section{Determination of Nitrate}

Lovibond Nesseler Kit (AF 355 (43550) disc 3/124) was used for this determination. The nitricol tablet was added to the relevant compartment and colour change produced was monitored in comparison with a standard colour [World Health Organization, 2004].

\section{Determination of odour}

The sample was poured into different clean odour free glass bottle and warmed to room temperature using water bath. The samples were shaken and the stopper of the bottle was removed. The odour was tested using the nose and the characteristic odour was recorded by five judges.[Madumelu et al, 2001].

\section{Determination of dissolved solids}

Dissolved solids of an effluent sample were determined from the formula: Dissolved Solid=Total Solid-Total Suspended Solid [Okafor and Aneke, 2006].

\section{Determination of colour}

Colour of the sample was determined by using the Lovinbond Comparator[Nessler RC50UK]. Disc NSA was fitted into the Comparator and 50 mills Nessler tube was filled with distilled water to $50 \mathrm{ml}$ mark and placed in the left hand compartment of the Nessler 50, day light north was faced with it and the disc was rotated until it matches the colour of the sample and the value was read in the bottom right hand corner of the Comparator in Hazen units. [Madumelu et al, 2001].

\section{Determination of chemical Oxygen Demand(COD) and Biochemical Oxygen} Demand (BOD)

The chemical and biochemical oxygen demands were measured according to standard methods described by Ademoroti[1996a].

\section{Determination of Chloride}

Potassium chromate $\left(\mathrm{K}_{2} \mathrm{CrO}_{4}\right)$ indicator of volume $1 \mathrm{~cm}^{3}$ was added to $5 \mathrm{~cm}^{3}$ sample and titrated against $0.01 \mathrm{M}$ silver nitrate to a reddish end point. The titre value was used for the determination of chloride concentration [Salami and Egwin 1997].

\section{Determination of Sodium, Potassium, Calcium and Magnesium ions}

One thousand parts per million stock solution of sodium $\left(\mathrm{Na}^{+}\right)$, potassium $\left(\mathrm{K}^{+}\right)$, calcium $\left(\mathrm{Ca}^{2+}\right)$ and magnesium $\left(\mathrm{Mg}^{2+}\right)$ were prepared. Both the standard $(\mathrm{Na}, \mathrm{K}, \mathrm{Ca}, \mathrm{Mg})$ and sample solutions as well as the blank solutions were aspirated using a flame photometer (GallenKamp BKL - 210) with the filter of $\mathrm{Na}, \mathrm{K}, \mathrm{Ca}$ and $\mathrm{Mg}$ in place and the readings of elements in the sample solutions recorded as described by Salami and Egwin (1997).

\section{Determination of Cyanide}

Thirty mills of the effluent as well as soil sample solutions were taken separately in the presence of a buffer solution, thus releasing the bound glycosidic acid. The resulting acid was distilled into 0.IM hydrochloric acid leach and after acidulation, the cyanide acid was mixed with bromine water forming bromine cyanide. When treated with pyridine and 2aminobenzoate acid, a red colour was observed and it's colour intensity was measured using a flame photometer (Ademoroti, 1996b). 


\section{Determination of Sulphate}

Concentrated $\mathrm{HCl}$ of $5 \mathrm{~cm}^{3}$ was separately added to $100 \mathrm{~cm}^{3}$ effluent and soil sample solution and each of the mixture heated to dryness and the residues were dissolved in $5 \mathrm{~cm}^{3}$ conc $\mathrm{HCl}$ while the insoluble silica was filtered and the filtrate diluted to $100 \mathrm{~cm}^{3}$ at $\mathrm{pH} 4$ to 5.5 . On heating each of the filtrate to boiling with addition of barium chloride solution, a white precipitate was formed. The filtrate was digested at $80-90^{\circ} \mathrm{C}$ for 3hours, filtered, dried and weighed to a constant weight in a pre-weighed evaporating dish. The value of sulphate was estimated following the methods used by Salami and Egwin (1997).

\section{Statistical Analysis}

Results were compared by analysis of variance (ANOVA) at 0.05 level of significance as described by Oyeka (1996).

\section{RESULTS AND DISCUSSION}

Physical and chemical characteristics of cassava effluents from five (5) locations of garri processing industries in Bida town are shown on Table 1.

The electrical conductivity of the five effluent samples was low indicating low presence of conducting ions while the $\mathrm{pH}$ values showed that these effluents are acidic. World Health Organization (2004) admissible limit for $\mathrm{pH}$ value in effluent waters is $6.5-8.5$ [Ademoroti, 1996b]. The low values of $\mathrm{pH}$ may be attributable to the presence of prussic acid [Gibbon and Pain, 1985] hence the high values of alkalinity as shown on table 1 . Generally, all the effluents have slightly irritating odour and this goes to explain the odious smell that is normally associated with garri processing industry and its surrounding.

According to Ademoroti (1996b), water quality is low when its dissolved oxygen is lower than $9.2 \mathrm{ppm}$ and the suspended solid is higher than $9.2 \mathrm{ppm}$. Therefore, the effluent if untreated before discharge into the environment is a potential source of water pollution within the vicinity. The level of cyanide content was observed to be very high 0.29 to $0.5 \mathrm{ppm}$ for the effluent and $0.3-0.62 \mathrm{ppm}$ for soil sample solutions (Table 2 ) as against W.H.O. (2004) permissible limit of $0.07 \mathrm{ppm}$. The highest value was obtained from the sample collected from Efumayaki followed by those of Masaga, Edogifu, Kotaworo and Efumadami. However, cyanide level is higher than $0.2 \mathrm{ppm}$, this can definitely cause ill-health and ultimately death in human and aquatic biota [Ademoroti, 1996b].

In a study by Ademoroti [1986], it was shown that there is a significant linear relationship between COD and $\mathrm{BOD}_{5}$ of domestic, poultry and brewery wastewaters. Since the greater the decomposable organic matter, the greater the $\mathrm{BOD}_{5}$ value [Ademoroti, 1996a], the results of this study imply high levels of micro-organisms as a result of high values of $\mathrm{BOD}_{5}$ which are 511,531, 557, 600 and $618 \mathrm{ppm}$ for Kotaworo, Efumayaki, Masaga, Edogifu and Efumadami respectively. The CODs are equally very high showing that these effluent wastewaters contained high amounts of organic matter. Again, even where there is no World Health Organisation's standard admissible limits for alkalinity, the values of 129 to $150 \mathrm{mg} / \mathrm{CaCO}_{3}$ in the effluent wastewaters may contribute to hardness of underground water resources. This was shown in high levels of hardness of the wastewaters which were 320 to 600ppm.

The colours of these effluents have exceeded their threshold of 5 Hazen for industrial wastewater
[W.H.O; 2004].Excessive colours above the permissible limit are primarily due to dissolved substances and some degraded products. These coloured effluents are at times resistant to chemical and biological degradation and intractable to separate by conventional treatment methods [Jon and Tuttle, 1997]. According to George et al (2003), the ratio of BOD/COD for an untreated wastewater is normally from 0.3 to 0.8 but that for cassava effluent under investigation ranged from 1.76 to 4.43 which are high and above the admissible limit. These pollutant indicators as shown on table 1 can therefore be reduced in their units when the effluents are treated with suitable active carbons as documented by Okafor and Egwin [2004] in which it was reported that treatment of cassava effluent with locally developed adsorbents reduced BOD and COD by up to 50 and $75 \%$ respectively. This has become necessary because these indicators have exceeded their threshold limits.

Table 2 shows the result of soil analysis done on the soils from the five sites studied

Calcium, magnesium, sodium and potassium ions generally increased as the depth of soil collection increased. From Table 2, it was equally observed that the cyanide concentration increased with increasing depth of the soil sample. This implies that very soon, underground water resources within Bida town may be heavily polluted with cyanide. A two-way analysis of variance showed that these ions increased in concentration as one moved from top soil to a depth of 1metre since $\mathrm{F}$ calculated is greater than the critical value of $F$. This will constitute a great danger to humans, animals and aquatic lives. This trend was equally confirmed by a decrease in the $\mathrm{pH}$ values as one moves down the soil.

The top soil from Efumayaki had the highest concentration of cyanide followed by those of Masaga and Edogifu while those from Kotaworo and Efumadami contain the least. At a depth of $50 \mathrm{~cm}$, Masaga sample was the highest followed by those of Efumayaki, Kotaworo, Edogifu and lastly Efumadami's sample. Sample collected at $1 \mathrm{~m}$ depth followed exactly the same trend as for sample collected at $50 \mathrm{~cm}$ depth. These cyanide values are above the allowable value of $0.07 \mathrm{ppm}$, while the values obtained from the study were $0.3-$ $0.6 \mathrm{ppm}$. This might trigger off a serious cyanide pollution of underground water resources within the vicinity. In a similar study by Madumelu and Okafor (2002) in areas in Bida without garri processing industries, it was observed that cyanide level was from 0-0.14 ppm in the 24 groundwater from wells in Bida metropolis. Therefore, these results should be a source of major concern to people with garri processing industries within their surroundings not only in Bida but to all others who discharge such effluents indiscriminately without adequate prior treatment.

\section{CONCLUSION}

The effluent characteristics showed that some properties of the effluent exceeded the World Health Organisation standard for industrial wastewaters. The cyanide contamination in both the effluent and soil samples was very enormous. This portends a grievous consequence on the underground water resources in the immediate future. This is because cyanide is very lethal and $\mathrm{WHO}$ admissible limit is $0.07 \mathrm{ppm}$ but for the cassava effluent, the values were $0.029-0.5 \mathrm{ppm}$ while it was as high as 0.3-0.6 ppm for soil solution samples approximately 77$89 \%$ above permissible limits. 
Table 1: Physical and Chemical Characteristics of Cassava Effluents from some garri processing areas of Bida, Niger State, Nigeria.

\begin{tabular}{|c|c|c|c|c|c|c|}
\hline Variables & Masaga & Efumayaki & Kotaworo & Edogifu & Efumadami & $\begin{array}{l}\text { WHO(2004) } \\
\text { Standard }\end{array}$ \\
\hline $\mathrm{pH}$ & 4.5 & 4.3 & 4.3 & 4.1 & 4.0 & $6.5-8.5$ \\
\hline Alkalinity $\left(\mathrm{mg} / \mathrm{ICaCO}_{3}\right)$ & 150.0 & 140 & 141 & 130 & 129 & - \\
\hline Conductivity ( $\mu \mathrm{s} / \mathrm{cm})$ & 40 & 50 & 52 & 41 & 61 & 750.5 \\
\hline Temperature $\left({ }^{0} \mathrm{C}\right)$ & 21 & 22 & 21 & 23 & 25 & 21 \\
\hline Odour & Slightly Irritating & Slightly Irritating & Slightly Irritating & Slightly Irritating & Slightly Irritating & - \\
\hline Cyanide (ppm) & 0.4 & 0.5 & 0.3 & 0.33 & 0.29 & 0.07 \\
\hline BOD5(ppm) & 557 & 531 & 511 & 600 & 618 & 100 \\
\hline COD (ppm) & 198 & 120 & 290 & 320 & 400 & - \\
\hline $\mathrm{BOD}_{5} / \mathrm{COD}$ & 2.81 & 4.43 & 1.76 & 1.88 & 1.55 & - \\
\hline Dissolved oxygen (ppm) & 7.0 & 6.0 & 4.5 & 4.63 & 4.2 & 9.2 \\
\hline Total Solid (ppm) & 483 & 420 & 512 & 470 & 700 & - \\
\hline Suspended Solid (ppm) & 221 & 183 & 210 & 194 & 315 & 25 \\
\hline Dissolved Solid (ppm) & 262 & 237 & 302 & 276 & 385 & 1000 \\
\hline Nitrate (ppm) & 0 & 0 & 0 & 0 & 0 & 50 \\
\hline Hardness (ppm) & 600 & 320 & 550 & 481 & 420 & - \\
\hline Colour (Hazen) & 23 & 21 & 25 & 22 & 23 & 5 \\
\hline Chloride(ppm) & 120 & 107 & 100 & 130 & 160 & - \\
\hline Sulphate(ppm) & 0.54 & 0.50 & 15.49 & 0.50 & 0.43 & \\
\hline
\end{tabular}


Table 2: Physicochemical characteristics of soil samples from five different sites used for garri processing in Bida, Niger State, Nigeria.

\begin{tabular}{|c|c|c|c|c|c|c|c|}
\hline \multicolumn{8}{|c|}{ Masaga Site } \\
\hline Sample & $\begin{array}{l}\text { pH } \\
\text { (mg/l) }\end{array}$ & $\begin{array}{l}\mathrm{Ca}^{2+} \\
(\mathrm{mg} / \mathrm{l})\end{array}$ & $\begin{array}{l}\mathbf{M g}^{2+} \\
(\mathrm{mg} / \mathrm{I})\end{array}$ & $\begin{array}{l}\mathrm{Na}^{+} \\
(\mathrm{mg} / \mathrm{l})\end{array}$ & $\begin{array}{l}\mathrm{SO}_{4}{ }^{2-} \\
(\mathrm{mg} / \mathrm{I})\end{array}$ & $\mathrm{K}^{+}(\mathrm{mg} / \mathrm{I})$ & $\begin{array}{l}\text { Cyanide } \\
\text { (ppm) }\end{array}$ \\
\hline Top Soil & 5.0 & 3.28 & 6.84 & 0.174 & 0.56 & 0.044 & 0.40 \\
\hline $\begin{array}{l}50 \mathrm{~cm} \\
\text { Depth }\end{array}$ & 4.5 & 3.44 & 7.20 & 0.201 & 0.78 & 0.052 & 0.60 \\
\hline 1m Dept & 3.2 & 3.70 & 7.34 & 2.250 & 0.82 & 0.063 & 0.62 \\
\hline \multicolumn{8}{|c|}{ Efumayaki Site } \\
\hline Top Soil & 4.4 & 2.94 & 5.45 & 0.20 & 0.52 & 0.033 & 0.51 \\
\hline $\begin{array}{l}\text { 50cm } \\
\text { Depth }\end{array}$ & 4.2 & 2.98 & 5.62 & 0.24 & 0.62 & 0.041 & 0.55 \\
\hline $1 \mathrm{~m}$ Dept & 4.0 & 3.10 & 5.77 & 0.31 & 0.72 & 0.050 & 0.58 \\
\hline \multicolumn{8}{|c|}{ Kotaworo Site } \\
\hline Top Soil & 4.1 & 3.01 & 5.30 & 0.22 & 0.50 & 0.011 & 0.30 \\
\hline $\begin{array}{l}50 \mathrm{~cm} \\
\text { Depth }\end{array}$ & 3.9 & 3.04 & 5.41 & 0.26 & 0.53 & 0.015 & 0.50 \\
\hline $1 \mathrm{~m}$ Dept & 3.7 & 3.12 & 5.62 & 0.31 & 0.56 & 0.018 & 0.54 \\
\hline \multicolumn{8}{|c|}{ Edogifu Site } \\
\hline Top Soil & 4.1 & 3.04 & 5.12 & 0.180 & 0.52 & 0.042 & 0.34 \\
\hline $\begin{array}{l}\text { 50cm } \\
\text { Depth }\end{array}$ & 3.9 & 3.82 & 5.94 & 0.182 & 0.53 & 0.045 & 0.40 \\
\hline 1m Depth & 3.5 & 3.92 & 6.00 & 0.185 & 0.57 & 0.050 & 0.42 \\
\hline \multicolumn{8}{|c|}{ Efumadami Site } \\
\hline Top Soil & 4.10 & 3.10 & 5.42 & 0.160 & 0.45 & 0.021 & 0.30 \\
\hline $50 \mathrm{~cm}$ Dept & 4.00 & 3.28 & 5.50 & 0.170 & 0.51 & 0.030 & 0.34 \\
\hline 1m Dept & 3.80 & 3.40 & 6.10 & 0.210 & 0.63 & 0.035 & 0.36 \\
\hline
\end{tabular}

All local communities involved with garri production should be enlightened on the dangers inherent in discharging these effluents into the environment without treating them to reduce the pollutants contained in them. Effluents from

\section{REFERENCES}

Ademoroti, C.M.A. (1986). Model to Predict BOD from COD values of

Domestic, Poultry and Brewery wastewaters, Effluent and Water Treatment Journal, 26 (3), 8084.

Ademoroti, C.M.A. (1996a). Standard Methods for Water and Effluents Analysis, Foludex Press Ltd., Ibadan, Nigeria.

Ademoroti, C.M.A. (1996b). Environmental Chemistry and Toxicology, Foludex Press Ltd., Ibadan, Nigeria.

Food and Agricultural Organisation (2004), The Global Cassava Development Strategy, Published by Food and Agricultural Organisation.

George, T; Franklin; L. B. and Davi; H. S. (2003). Wastewater Engineering, Treatment and Refuse, $4^{\text {th }}$ edition, Tata McGraw-Hill Publishing Company Ltd, New Delhi, pp 97 -98.

Gibbon, D and Pain, A. (1985). Crops of the Drier Region of the Tropics, England Longman Group, U.K.

Okafor, J. O. and Aneke, N. A. G. (2006). Characterization of Adsorbents for the Purification of Cocoa-cola Effluent, Journal of the Nigerian Society of Chemical Engineers, 21(1and2), pp 20 -24. garri processing industries should therefore be treated with locally developed powdered adsorbents before discharge into the environment.

Okafor, J.O. and Egwim E. (2004). Effect of Chemically and Physically treated Adsorbents on wastewater from Garri Processing Industry, $27^{\text {th }}$ Annual International Conference of Chemical Society of Nigeria, Benin City, Nigeria. $21^{\text {st }}$ to $22^{\text {nd }}$ August.

Oyeka, C. A. (1996). An Introduction to Applied Statistics, $7^{\text {th }}$ Edition, nober avocation publishing company, Enugu, pp 218-246.

Madumelu, P. C. and Okafor, J. O. and Akoma, O. (2001). The Effect of some Additives on the Physical and Organoleptic Quality Characteristics of Fermented Cassava, Polymath Journal, 2(1), pp 3-4.

Madumelu, P. C. and Okafor, J. O. (2002). Nitrate Pollution of Groundwater in Bida, Nigeria, Polymath Journal 3(1): pp 21-23, Nigeria.

Jon, W. Y. and Tuttle, W. N. (1997). Reduction of hydrocarbon emission from air through pressure swing regeneration of activated carbon, American Institute o Chemical Engineerings' Conference, U. S.A; pp1-8.

Salami, S.J. and Egwin I.N. (1997). Impact of Tannery Effluents on the Quality of Receiving Stream, African Journal of Natural Sciences, 2(1) pp 1720.

World Health Organisation (2004). Maximum Allowable Concentration of Selected Water Quality Variables. 